\section{Commission seeks to 'blow the whistle' on unethical decisions}

[LONDON] The role of Unesco's newly created Commission on the Ethics of Scientific Knowledge and Technology (COMEST) is to "blow the whistle", according to its director-general, Vidgís Finnbogadóttir, speaking after the close of its first meeting in Oslo last month.

A main theme at the meeting was the ethics of the information society. Finnbogadóttir, a former president of Iceland, says it was apparent that very little work had been done in this area, even though "the ethical issues are very clear".

"A greater part of the world does not have access [to information technology], and this alienates them and widens the gap between those who have knowledge and those who do not," she says. "The expense of technology deprives many people - this is unethical."

Finnbogadóttir says that COMEST's mission is to identify problems and find a voice: "We want to define the most burning issues and get the attention of decision-makers."

One key topic raised at the meeting was the issue of irreversible action in the environment, such as the depletion of resources or the destruction of a landscape. Citing a case in Norway in which the building of a hydropower station had created local flooding, Finnbogadóttir said that COMEST would bring such poor ethical decisions to the attention of ordinary citizens.

She emphasizes that problems will be continuing, and that COMEST will give its opinion regularly. It will report on its mission and activities to the World Conference on Science in Budapest.

Full text: http://helix.nature.com/wcs/a30.htm

\title{
US academy backs plan for multinational expert panels
}

[WASHINGTON] The US National Academy of Sciences is planning to help create an InterAcademy Centre, run by a multinational board, as a mechanism for setting up and running panels of top-level scientific, engineering and health experts.

Describing the plans in Washington last month, academy president Bruce Alberts said the new body would operate as an international version of the academy's National Research Council. The expert panels would advise global institutions such as the United Nations and the World Bank on issues of critical importance to them.

Alberts said he was keen for the academy to move into the international arena "to ensure that the type of science and technology advice that so wisely informs policy at home can help inform decisions abroad". He pointed out that four years ago it had joined with the scientific academies of other nations to create the InterAcademy Panel on International Issues, an informal network now totalling 80 academies.

It had also developed a website to promote rapid communication between these academies as they prepare for a Conference of Academies, to be held in Tokyo in May 2000, which will address "the many opportunities and challenges for scientists as the world accommodates an estimated 10 billion people in the 21st century".

Alberts pointed out that policy-making institutions will face increasingly complicated issues involving questions of scientific validity and balance. "The world badly needs an impartial mechanism, based only on science, to promote smarter decision-making

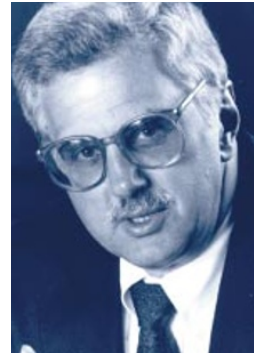

on such issues as agricultural strategies for Africa, safe drinking water in Bangladesh and energy options for Asia," he said.

"The world's academies and their counterpart organizations are the ideal institutions Alberts: seeks global for providing indepensolution to problems. dent, credible, timely, multinational advice on a broad range of such issues - and we are presently working to help them accept this important responsibility."

In his speech, delivered to the academy's annual meeting, Alberts also urged the world's scientists to work together to create a communication network designed to empower scientists and scientific organizations with valuable knowledge and skills.

He suggested that the world's major scientific organizations cooperate to connect all scientists to the World-Wide Web, where necessary by providing subsidized Internet access through commercial satellite networks, and to take responsibility for generating "scientifically validated knowledge resources", made available free on the web, in preparation for a time when universal Internet access for scientists is achieved in developing and industrialized nations.

"By taking full advantage of new information technologies, the scientific community has an unprecedented opportunity to close the vast 'knowledge gap' between all peoples.' Full text: http://helix.nature.com/wcs/c15.htm

\section{British government under fire for falling to back Unesco efforts}

[LONDON] British supporters of Unesco remain at loggerheads with the government over the extent to which it is prepared to make use of Britain's membership of the UN agency, which it rejoined in 1997 after a 12year absence.

The Labour government rejoined in order to fulfil a commitment the party had made before coming to power in the 1997 election. Since then, however, Whitehall departments have been reluctant to provide additional financial support for Unescorelated activities in Britain on top of the annual membership fee paid to the agency.

Last week, the two joint chairmen of the
UK Unesco Forum - Dennis Chisman and Malcolm Harper - wrote to Jack Cunningham, the minister for the Cabinet Office, protesting that there appeared to be "overwhelming evidence" that the government's commitment to integrated government was not being followed in the case of policy towards Unesco.

They point out that only one government department - the Department for International Development - is prepared to make a significant contribution to the cost of servicing a national commission.

The Department for Education and Employment had agreed to pay for the work of a separate committee in its field, but not to help towards common costs. And, while the Foreign and Commonwealth Office had offered a "token contribution" of $\mathfrak{E 5 , 0 0 0}$ (US\$8,130), other departments, including the departments of trade and industry and of the environment, refuse to contribute.

"The national commissions of all our European Union partners have always been fully funded by government," the two authors say in their letter to Cunningham. "There are real policy issues of policy coherence which urgently call for your involvement." Full text: http://helix.nature.com/wcs/b36.htm 